\title{
Market Activities in the Area of Product. A Comparison of Dairy Cooperatives from Świętokrzyskie and Małopolskie Voivodeships
}

\author{
Izabela KONIECZNA \\ The Jan Kochanowski University in Kielce, Kielce, Poland \\ izabela.konieczna@ujk.edu.pl
}

\begin{abstract}
The purpose of this paper is an analysis of activities affecting the value for customers implemented by cooperatives producing dairy products from the Świętokrzyskie and Małopolskie Voivodeships from Poland on different markets in the sphere of product. Executives were asked during the direct interview to indicate activities that according to their opinion are affecting the value for customers on home voivodeship market, UE markets, other voivodeships markets, and other main markets. They had to indicate if they offer organic products, products with high nutritional value, natural products, products with health properties, products in attractively designed packages, products in convenient packages, or products in packages that are pattern-matched to others. They could indicate as many activities as they implement. The analysis of conducted research shows that market activities in the area of product are in different extent implemented by cooperatives producing dairy products from the Świętokrzyskie and Małopolskie Voivodeships. The research results also show that cooperatives from both voivodeships do not implement any activity on EU market.
\end{abstract}

Keywords: Market Activities, Product, Cooperatives.

\section{Introduction}

Companies need to know where their business sector is going, as well as understand their customers to remain at the forefront of competition, often to work with them in terms of future planning and rapid implementation [16]. It is very important, because how customers perceive the products or services of the organization compared to what they have heard or seen about other companies or organizations, and in the light of their experience with this organization (or product) determines customer satisfaction [15]. The markets are composed of consumers with different tastes, incomes, cultures, beliefs, expectations, norms and motives. These differences also affect the values owned and will be gained [16]. Moreover, the requirements of customers expecting constantly increasing quality and services at lower costs are becoming more and more visible [14]. To understand how customers define value, the company must focus on the outcomes that customers want when they buy and use company's products [13]. 
Therefore, marketing managers involved in the development of a business strategy should take these details into account [16].

The purpose pf the paper is an analysis of activities affecting the value for customers implemented by cooperatives producing dairy products from the Świętokrzyskie Voivodeship and Małopolskie Voivodeship from Poland on different markets in the sphere of the product. The activities within the framework of product included: offering organic products, offering products with high nutritional value, offering natural products, offering products with health properties, offering products in attractively designed packages, offering products in packages that are pattern-matched to others, and offering products in convenient packages.

\section{A Characteristic of Product}

The general purpose of any company is determining and satisfying the needs of customers using products that are available and have certain value, and whose features are clearly defined [3]. In essence, to anything offered by a firm to provide customer satisfaction refers the term "product". It can be a single product, a combination of products, a product-service combination, or several related products and services [3]. We can distinguish three forms of products that are in consonance with the marketing concept which guides a marketer to offer a product that fulfills the needs and wants of the target market [7]: 1 . the core product (the real core benefit or service), 2. the embodied product (the physical good or delivered service that provides the expected benefit), and 3. the augmented product (embodied product plus all those other factors that are necessary to support the purchase and any post-purchase activities) [1]. The product also has the societal aspect. That is, the product offered by a company is expected to be not only user-friendly (the one who owns and consumers the product) but also eco-friendly (the consumption of the product should not cause environmental degradation) [7]. To enhance a company's current idea generation methods and vastly improve its development pipeline can a method that focuses on the product - What is essential? What can be removed, rearranged, or replicated in new ways? [5]. When customers buy products they are just not buying the simple functional aspect a product offers, there are other complexities involved in the purchase [1]. E. Miracle indicated certain product characteristics. These are:

- Unit value;

- Significance of each individual purchase to the consumer;

- Time and effort spent purchasing by consumers;

- Rate of technological change (including, fashion changes);

- Technical complexity;

- Consumer need for service (before, during, or after the sale);

- Frequency of purchase;

- Rapidity of consumption;

- Extent of usage (number and variety of consumers and variety of ways in which the product provides utility) [12]. 
From the consumer's viewpoint, a product is a bundle of benefits; some of those benefits are essential requirements, others are less important but still good to have, still others are not really relevant [2]. The benefits that the consumers want from the product can be divided into four types - basic product benefits, use benefits, package benefits, psychological benefits (table 1). According to Hokanson, factors that affect customer satisfaction include courteous employees, friendly employees, helpful employees, knowledgeable employees, billing timeliness, accuracy of billing, competitive pricing, good value, billing clarity, service quality and quick service [6].

Table 1. The benefits that the consumers want from the product [4].

\begin{tabular}{ll}
\hline Benefits & Items \\
\hline Basic product benefits & $\begin{array}{l}\text { physical characteristics (such as size, shape, color), sensory qualities, } \\
\text { chemical composition, safety features and nutritional value. } \\
\text { information on use, convenience in buying and carrying, attractive } \\
\text { presentation, easy preparation, recipes and nutritional information. } \\
\text { Use benefits }\end{array}$ \\
$\begin{array}{l}\text { Package benefits } \\
\text { Psychological benefits }\end{array}$ & fun and friendliness, prestige, healthiness, aesthetics. \\
\hline
\end{tabular}

\section{Activities Affecting the Value for Customers in the Area of the Product - Research Results}

Research on activities affecting the value for customers in the area of the product was conducted in cooperatives producing dairy products from the Świętokrzyskie and Małopolskie Voivodeships, which had given their consent. The research tool was an interview questionnaire. The questionnaire was sent to all cooperatives that produce dairy products from the Świętokrzyskie Voivodeship and Małopolskie Voivodeship. Due to the willingness of representatives of cooperatives to participate in the research, interviews were carried out on a sample of $41 \%$ of cooperatives producing dairy products from both voivodeships. Executives were asked to indicate activities affecting the value for customers on such markets as home voivodeship, other voivodeships, UE markets, and other main markets. The results of the interviews are presented in Tab. 2, Fig. 1 and Fig. 2.

When analyzing Table 2 and Figure 1 it is seen that:

- On the home voivodeship market one-third of cooperatives from Świętokrzyskie Voivodeship and one quarter of cooperatives from Małopolskie Voivodeship are offering organic products, products with health properties, and products in attractively designed packages. In the same time one-third of cooperatives from Świętokrzyskie Voivodeship and half of cooperatives from Małopolskie Voivodeship are offering natural products and products in packages that are patternmatched to others. Moreover, 55\% of cooperatives from Małopolskie Voivodeship are offering products with high nutritional value, while cooperatives from Świętokrzyskie Voivodeship do not implement such activity. Cooperatives from 
Świętokrzyskie Voivodeship eighter do not offer products in convenient packages, whereas one quarter of cooperatives from Małopolskie Voivodeship do.

Table 2. Activities affecting the value for customers implemented by cooperatives producing dairy products from the Świętokrzyskie and Małopolskie Voivodeships on individual markets in the sphere of the product.

\begin{tabular}{|c|c|c|c|c|c|c|c|c|}
\hline \multirow[t]{2}{*}{ Activity } & \multicolumn{2}{|c|}{$\begin{array}{c}\text { Home } \\
\text { voivodeship* }\end{array}$} & \multicolumn{2}{|c|}{$\begin{array}{c}\text { Other } \\
\text { voivodeships* }\end{array}$} & \multicolumn{2}{|c|}{ UE markets* } & \multicolumn{2}{|c|}{$\begin{array}{l}\text { Other main } \\
\text { markets* }\end{array}$} \\
\hline & $\dot{S}^{* *}$ & $\mathrm{M}^{* * *}$ & $\dot{S}^{* *}$ & $M^{* * *}$ & $S^{* * *}$ & $\mathrm{M}^{* * *}$ & $S^{* *}$ & $\mathrm{M}^{* * *}$ \\
\hline $\begin{array}{l}\text { Offering } \\
\text { organic } \\
\text { products }\end{array}$ & $33 \%$ & $25 \%$ & $33 \%$ & $25 \%$ & $0 \%$ & $0 \%$ & $0 \%$ & $25 \%$ \\
\hline $\begin{array}{l}\text { Offering } \\
\text { products with } \\
\text { high } \\
\text { nutritional } \\
\text { value }\end{array}$ & $0 \%$ & $50 \%$ & $0 \%$ & $25 \%$ & $0 \%$ & $0 \%$ & $0 \%$ & $0 \%$ \\
\hline $\begin{array}{l}\text { Offering } \\
\text { natural } \\
\text { products }\end{array}$ & $33 \%$ & $50 \%$ & $33 \%$ & $50 \%$ & $0 \%$ & $0 \%$ & $0 \%$ & $0 \%$ \\
\hline $\begin{array}{l}\text { Offering } \\
\text { products with } \\
\text { health } \\
\text { properties }\end{array}$ & $33 \%$ & $25 \%$ & $33 \%$ & $25 \%$ & $0 \%$ & $0 \%$ & $0 \%$ & $0 \%$ \\
\hline $\begin{array}{l}\text { Offering } \\
\text { products in } \\
\text { attractively } \\
\text { designed } \\
\text { packages }\end{array}$ & $33 \%$ & $25 \%$ & $0 \%$ & $25 \%$ & $0 \%$ & $0 \%$ & $0 \%$ & $0 \%$ \\
\hline $\begin{array}{l}\text { Offering } \\
\text { products in } \\
\text { packages that } \\
\text { are pattern- } \\
\text { matched to } \\
\text { others }\end{array}$ & $33 \%$ & $50 \%$ & $33 \%$ & $50 \%$ & $0 \%$ & $0 \%$ & $0 \%$ & $0 \%$ \\
\hline $\begin{array}{l}\text { Offering } \\
\text { products in } \\
\text { convenient } \\
\text { packages }\end{array}$ & $0 \%$ & $25 \%$ & $0 \%$ & $0 \%$ & $0 \%$ & $0 \%$ & $0 \%$ & $0 \%$ \\
\hline
\end{tabular}


- On other voivodeships markets one-third of cooperatives from Świętokrzyskie Voivodeship and one quarter of cooperatives from Małopolskie Voivodeship are offering organic products and products with health properties. In the same time onethird of cooperatives from Świętokrzyskie Voivodeship and half of cooperatives from Małopolskie Voivodeship are offering natural products and products in packages that are pattern-matched to others. Furthermore, $55 \%$ of cooperatives from Małopolskie Voivodeship are offering products with high nutritional value, and products in attractively designed packages, whereas cooperatives from Świętokrzyskie Voivodeship do not implement these activities. Cooperatives from both voivodeships do not offer products in convenient packages on these markets.

- On EU markets cooperatives from both voivodeships do not implement any activity affecting the value for customers in the area of the product.

- On other main markets only $25 \%$ of cooperatives from Małopolskie Voivodeship offer organic products. Both cooperatives from Świętokrzyskie i Małopolskie Voivodeships do not implemented other activities.

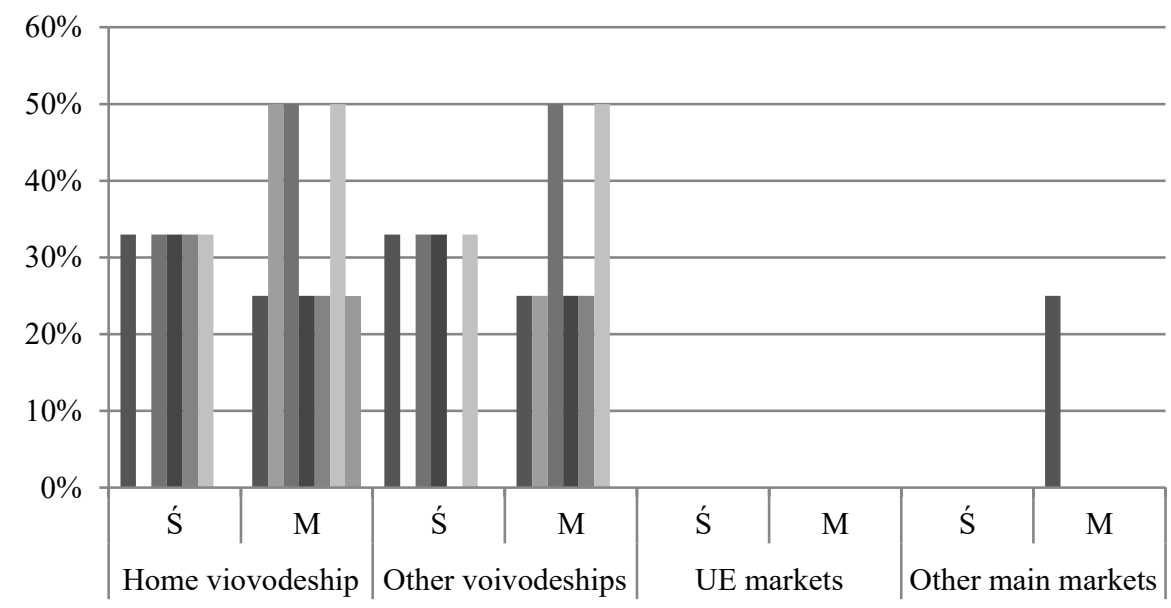

- Offering organic products

Offering products with high nutritional value

- Offering natural products

- Offering products with health properties

- Offering products in attractively designed packages

Offering products in packages that are pattern-matched to others

- Offering products in convenient packages

Ś - Świętokrzyskie Voivodeship

M - Małopolskie Voivodeship

Fig. 1. Chart for data from table 1.

An analysis of Table 2 and Figure 2 shows that:

- Organic products offer 33\% of cooperatives from Świętokrzyskie Voivodeship and one quarter of cooperatives from Małopolskie Voivodeship on the home market and 
on other voivodeships markets. Moreover, one quarter of cooperatives from Małopolskie Voivodeship offer such products on other main markets, while cooperatives from Świętokrzyskie Voivodeship do not offer this kind of products on this market. Organic products are not offered on EU markets.

- Products with high nutritional value are only offered by cooperatives from Małopolskie Voivodeship on the home market (50\%), and on other voivodeships markets (25\%). Cooperatives from Świętokrzyskie Voivodeship do not offer such products.

- Natural products offer one-third of cooperatives from Świętokrzyskie Voivodeship and $50 \%$ of cooperatives from Małopolskie Voivodeship on the home market and on other voivodeships markets. On the EU market and on other main markets this kind of products are not offered.

- Products with health properties are offered by one-third of cooperatives from Świętokrzyskie Voivodeship and by $25 \%$ of cooperatives from Małopolskie Voivodeship on the home market and on other voivodeships markets. On the EU market and on other main markets is not offered this kind of products.

- Products in attractively designed packages offer one-third of cooperatives from Świętokrzyskie Voivodeship on the home market. On other indicated markets cooperatives from Świętokrzyskie Voivodeship do not offer such products. In the same time products in attractively designed packages are offered by one quarter of cooperatives from Małopolskie Voivodeship on the home market and on other voivodeships markets, while on other indicated markets they are not offered.

- Products in packages that are pattern-matched to others are offered by one-third of cooperatives from Świętokrzyskie Voivodeship and 50\% of cooperatives from Małopolskie Voivodeship on the home market and on other voivodeships markets. On other main markets and on the EU market this kind of products is not offered.

- Products in convenient packages offer one quarter of cooperatives from Małopolskie Voivodeship on the home market. On other indicated markets they do not offer such products. In the same time cooperatives from Świętokrzyskie Voivodeship do not offer products in convenient packages at all. 


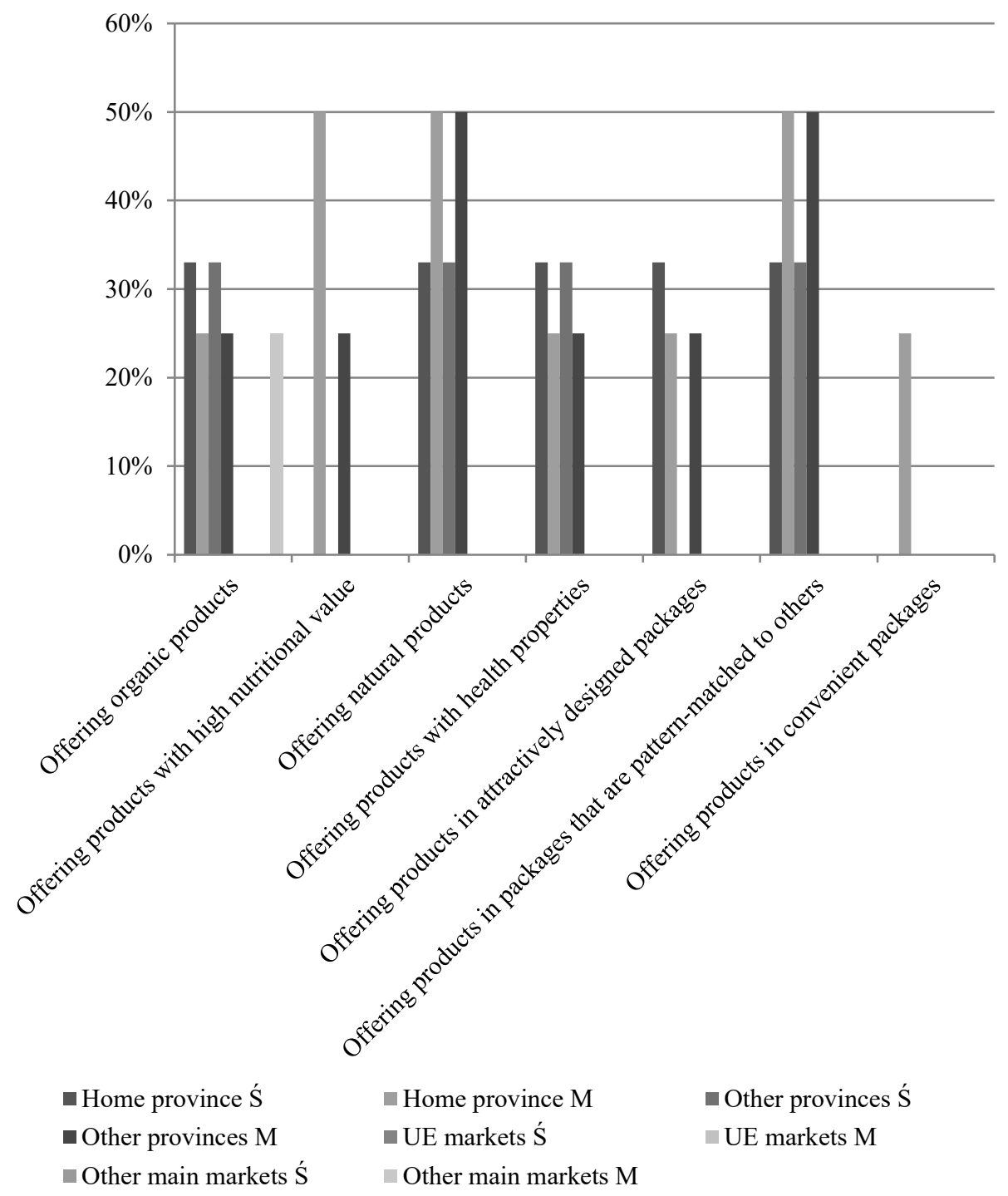

Ś - Świętokrzyskie Voivodeship

M - Małopolskie Voivodeship

Fig. 2. Chart for data from table 1.

\section{Discussion}

I. Konieczna analyzed the assessment of cooperatives producing dairy products from the Świętokrzyskie and Małopolskie Voivodeships of the validity of the features of the offer for customers in the area of the product. Cooperatives' executives indicated 
features of the offer, which according to them are valid, for such customers as wholesalers, consumers, independent retail grocery stores, intermediary agents in food trade, companies - users (gastronomy), local retail chains, large retail chains, other institutional purchasers, and other dairies. The results of the research show that cooperatives from Świętokrzyskie and Małopolskie Voivodeships rather differently assess the validity of the offer features for customers in the sphere of the product [11]. In another article I. Konieczna and P. Garasym showed the perception of future managers, Polish and Ukrainian about products offered by cooperatives. Respondents stated that the cooperatives offer products in the average extend in all indicated fields, i.e. innovation, ecology, quality, and package [9]. I. Konieczna in another article conducted an analysis of the features of the offer that are for customers important and have an influence on customers' value in the sphere of sales marketing, in the opinion of managers of cooperatives producing dairy products from Świętokrzyskie Voivodeship. As research results show for each type of customers are different features extremely important, i.e. the price of the product for wholesalers, the range of pre-, peri-, and after-sales services for local retail chains, the payment terms for consumers, and promotional prices, the price of pre-, peri-, and after-sales services, and the crediting of purchases for companies-users (gastronomy) [8].

\section{Conclusion}

Considering the results of research, it can be seen that, although activities connected with product affect the value for the customer, none of them is implemented by all cooperatives. What is seen that the focus and target of cooperatives from both voivodeships is put only on Polish market, because activities are implemented mostly on home voivodeship market and other voivodeships' markets. Only $25 \%$ of cooperatives from Małopolskie Voivodeship offer organic products on the other main markets. Besides, some activities are not implemented by cooperatives producing dairy products from Świętokrzyskie Voivodeship on the home voivodeship market and on other voivodeships' markets, while only one activity is not implemented on other voivodeships markets by cooperatives from Małopolskie Voivodeship. It is also seen that half of cooperatives producing dairy products from Małopolskie Voivodeship on both home market and on other voivodeships' markets implement such activities as offering natural products and offering products in packages that are pattern-matched to others. Increasing competition is likely to cause cooperatives in order to survive and develop the expansion of their activities to other markets. Furthermore, especially cooperatives from Świętokrzyskie Voivodeship that implement less activities than cooperatives from Małopolskie Voivodeship to be more competitive with high probability will have to expand the scope of activities in this area. 


\section{References}

1. Balnes, P., Fill, C., Page, K.: Marketing. 2nd edn. Oxford University Press, Oxford (2011).

2. Blythe, J.: Essentials of Marketing. 3rd edn. Prentice Hall, Harlow (2005).

3. Burnett, J.: Core Concepts of Marketing. 1st edn. Global Text Project, Zurich (2008).

4. Earle, M.D, Earle, R.L.: Creating New Foods. The Product Developer's Guide. 1st edn. Chadwick House Group Ltd, London (2000).

5. Goldenberg, J., Horowitz, R., Levav, A., Mazursky, D.: Finding your Innovation Sweet Spot. Harvard Business Review, 81(3), 120-129 (2003)

6. Hokanson, S.: The Deeper You Analyse, The More You Satisfy Customers. Marketing News, 29(1), 16 (1995).

7. Jayachandran, S.: Marketing Management. Text and cases. 1st edn. Excel Books, New Delhi (2006).

8. Konieczna I. The Validity of the Features of the Offer for Clients in the Sphere of Sales Marketing - the Assessment of Dairy Cooperatives from Świętokrzyskie Province. In: Primorac, Z., Bussoli, C., Recker, N. (eds.) Economic and Social Development (Book of Proceedings), 16th International Scientific Conference on Economic and Social Development - Legal Challenges of Modern World, pp. 817-826, Varazdin Development and Entrepreneurship Agency, University of Split, University North, Split, (2016).

9. Konieczna, I., Garasym, P.: Perception of the Products Offered by Cooperatives in Poland and Ukraine. In: Hittmar, S. (ed.) Theory of Management 7, pp. 139-145, University of Žilina, Žilina (2014).

10. Konieczna, I.: Działania rynkowe w obszarze produktu na przykładzie spółdzielni mleczarskich z województwa świętokrzyskiego. Prace Naukowe Uniwersytetu Ekonomicznego we Wrocławiu - Strategie. Procesy i praktyki 420, pp. 153-162 (2016).

11. Konieczna, I.: The validity of the features of the offer for customers in the area of the product. The comparison of the assessment of dairy cooperatives from the Świętokrzyskie and Małopolskie Provinces. In: Jedlička, P., Marešová, P., Soukal, I. (eds.) Double-blind peer-reviewed proceedings of the international scientific conference Hradec Economic Days 2018, pp. 417-427, University of Hradec Kralove, Hradec Kralove (2018).

12. Miracle, G.E.: Product Characteristics and Marketing Strategy. Journal of Marketing, 29, 18-24 (1965).

13. Sawhney, M.: Fundamentals of Customer Value. CIO Magazine, 4, 107-110 (2003).

14. Slater, S. F.: Developing a customer value-based theory of the firm. Journal of Academy of Marketing Science 25(2), 162-167 (1997).

15. Szwarc, P.: Researching Customer Satisfaction \& Loyalty: How to Find Out What People Really Think. 1st edn. Kogan Page, London \& Sterling (2005).

16. Yamamoto, G.T.: Understanding Customer Value Concept: Key to Success. First International Joint Symposium on Business Administration "Challenges for Business Administrators in the New Millennium, pp. 547-552 (2000). 